\title{
Surviving in Overijssel. An Analysis of Life Expectancy, 1812-1912
}

\section{By Sander Wennemers and Hilde Bras}

To cite this article: Wennemers, S. \& Bras, H. (2021). Surviving in Overijssel. An Analysis of Life Expectancy, $1812-1912$. Historical Life Course Studies, 10, 156-161. https://doi.org/10.51964/hlcs9586

\section{HISTORICAL LIFE COURSE STUDIES}

Not Like Everybody Else.

Essays in Honor of Kees Mandemakers

VOLUME 10, SPECIAL ISSUE 3

2021

GUEST EDITORS

Hilde Bras

Jan Kok

Richard L. Zijdeman 


\section{HISTORICAL LIFE COURSE STUDIES}

Historical Life Course Studies is the electronic journal of the European Historical Population Samples Network (EHPSNet). The journal is the primary publishing outlet for research involved in the conversion of existing European and nonEuropean large historical demographic databases into a common format, the Intermediate Data Structure, and for studies based on these databases. The journal publishes both methodological and substantive research articles.

\section{Methodological Articles}

This section includes methodological articles that describe all forms of data handling involving large historical databases, including extensive descriptions of new or existing databases, syntax, algorithms and extraction programs. Authors are encouraged to share their syntaxes, applications and other forms of software presented in their article, if pertinent, on the openjournals website.

\section{Research articles}

This section includes substantive articles reporting the results of comparative longitudinal studies that are demographic and historical in nature, and that are based on micro-data from large historical databases.

Historical Life Course Studies is a no-fee double-blind, peer-reviewed open-access journal supported by the European Science Foundation (ESF, http://www.esf.org), the Scientific Research Network of Historical Demography (FWO Flanders, http://www.historicaldemography.be) and the International Institute of Social History Amsterdam (IISH, http://socialhistory.org/). Manuscripts are reviewed by the editors, members of the editorial and scientific boards, and by external reviewers. All journal content is freely available on the internet at https://openjournals.nl/index.php/hlcs.

\section{Co-Editors-In-Chief:}

Paul Puschmann (Radboud University) \& Luciana Quaranta (Lund University)

hislives@kuleuven.be

The European Science Foundation (ESF) provides a platform for its Member Organisations to advance science and explore new directions for research at the European level. Established in 1974 as an independent non-governmental organisation, the ESF currently serves 78 Member Organisations across 30 countries. EHPS-Net is an ESF Research Networking Programme.

The European Historical Population Samples Network (EHPS-net) brings together scholars to create a common format for databases containing non-aggregated information on persons, families and households. The aim is to form an integrated and joint interface between many European and non-European databases to stimulate comparative research on the micro-level.

Visit: http://www.ehps-net.eu.
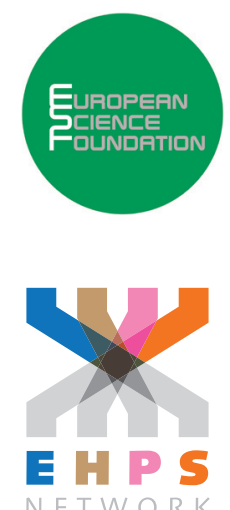


\title{
Surviving in Overijssel \\ An Analysis of Life Expectancy, 1812-1912
}

\author{
Sander Wennemers \\ University of Groningen \\ Hilde Bras \\ University of Groningen
}

\section{ABSTRACT}

The rise in life expectancy is one of the main processes of social change in the 19th century. In the Netherlands, regional differences in life expectancy, and their development, were huge. Therefore, studies on average life expectancy or studies, which examine the whole of the Netherlands do not fully capture the differential determinants of this process. This study focuses on social, economic, and geographic differences in life expectancy in 19th-century Overijssel using the Historical Sample of the Netherlands (HSN). Exploiting Cox regression, the influence of several factors on life expectancy are investigated. The article shows that birth cohort, urbanisation, and gender had an important relation with life expectancy in 19th-century Overijssel, while industrialisation, religion, and inheritance customs were not associated with age at death.

Keywords: Life expectancy, Historical demography, Cox regression, Regional variation, Survival analysis, Overijssel

e-ISSN: $\quad$ 2352-6343

DOI article: $\quad$ https://doi.org/10.51964/hlcs9586

The article can be downloaded from here.

This open-access work is licensed under a Creative Commons Attribution 4.0 International License, which permits use, reproduction \& distribution in any medium for non-commercial purposes, provided the original author(s) and source are given credit. See http://creativecommons.org/licenses/. 


\section{INTRODUCTION}

In the early 19th century there were huge differences in life expectancy in the Dutch provinces. Male inhabitants of the coastal provinces (Zeeland and Zuid-Holland) born between 1840 and 1851 lived on average 15 years less than men in the other provinces (Beekink, Boonstra, Engelen, \& Knippenberg, 2003). This can be explained by the poor quality of the water in the coastal provinces, which caused a higher mortality rate. During the 19th century the situation gradually improved. The life expectancy of inhabitants of coastal and inland provinces converged during this period. The demographic developments, however, did not follow an even pattern all over the Netherlands. For example, inhabitants of Overijssel had quite a high life expectancy of 42 years at the start of the 19th century. But during the century the trend of increasing life expectancy in Overijssel slowed down and lagged behind that in most other provinces (Engelen, 2009).

The determinants of life expectancy in the province of Overijssel as a whole have not been studied often. Particular regions of the province have been covered by previous studies, in which they were compared with other regions in the Netherlands. There are a number of interesting characteristics which makes a study of ageing in Overijssel interesting: the variation in inheritance systems, the existence of different industries in Twente, diverse levels of urbanisation, and the co-existence of Protestantism and Catholicism. This study sheds light on these and other characteristics, which could have had an influence on the differences in life expectancy in the 19th century. In this article, we use a database constructed by the Historical Sample of the Netherlands (HSN) with 4,239 life courses of men and women who were born and died in Overijssel between 1812 and 1912. We apply Cox regression analysis to analyse the influence of different factors on their life expectancy. In the remaining article, we will first give a brief description of the setting, followed by a sketch of the data, measures, and methods. Then we will focus on the results of the Cox-regression, and lastly, in the conclusion this study will be placed in a broader perspective.

\section{SETTING}

This study focuses on Overijssel, which is located in the mid-eastern part of the Netherlands. The western border is formed by the former Zuiderzee (currently IJsselmeer), the eastern part borders with Germany. Many Overijssel cities have been committed to trade for centuries. In the 17th century the Hanseatic league bound the cities of Overijssel to other cities in (northwest) Europe. Most of the rural inhabitants of Overijssel were self-sufficient and lived on small farms. The western part of the province is situated in a peat area, where cattle were raised and grain was grown. Peat extraction was common there; the newly extracted soil was very fertile, so farming in this area was quite profitable. Since peat is a good manure, the profits in newly extracted areas were high. Therefore, every once in a while, farmers extracted new soil. Quite apart from the higher profits, this was also a necessary procedure, since peat soil shrinks due to the extraction of water. After a couple of years with high profits, soils became wet and the profits declined. Farmers moved to an uncultivated piece of land and started over again (van Zanden, 1994).

The central (Salland) and eastern (Twente) part of Overijssel were located on sandy soils. Rye, buckwheat and oats were the main crops. Manure was needed here to make the grounds profitable enough to support families. Agriculture in this area was very labour-intensive. Husband, wife, and children had to work on the farm to produce enough food (and profit) for the family to consume. Most of the textile-factory labourers had a small plot of land to produce their own food. This was stimulated by the lack of surpluses and low wages. Labourers switched jobs often, looking for the most profitable job. At the end of the 19th century profits increased due to fertilising. Furthermore, the worldwide grain surpluses lowered food prices. Therefore, many farmers in Overijssel switched from the production of crops to livestock (van Zanden \& van Riel, 2004).

In the 19th century, Overijssel, and specifically the Twente region, industrialized rapidly. Many people migrated from the countryside to the cities, because there was a huge demand for laborers. At the start of the 20th century, Twente had over twenty industrialized factories, whereas there were only two in the rest of the province combined. Twente's industry was profitable, partly because the Nederlandse Handels Maatschappii (NHM) invested a lot of money in the Dutch factories to outcompete the Belgian industry. Because of the enormous success of the factories, inequality increased more in Twente than in the rest of the province (van Zanden \& van Riel, 2004).

In the agricultural parts of Salland and Twente family structure was characterized by stem families. This was also common in some other parts of the Netherlands, for example in the Achterhoek (province of 
Gelderland) and in parts of Limburg. Stem families are closely related to another common feature in these regions, namely impartible inheritance. Impartible inheritance is an old Saxon custom, which guaranteed that the whole property of the elder generation was passed on to only one heir of the younger generation. Impartible inheritance is also known as Anerbenrecht (Bras \& van Tilburg, 2007). Children who did not inherit the farm and land had two options. They could either leave the farm and make a living on their own somewhere else, or they could stay on the family farm and work for the heir and the rest of the family. Impartible inheritance could have been a reason why Twente industrialized very rapidly; there were many people without farms, who had to find a way to make a living on their own.

The Reformation divided the Netherlands in a Roman Catholic southeast and a Protestant northwest. The two parts were divided by an imaginary line, the so-called Rome-Reformatielijn. Noordwest-Overijssel and Salland were situated in the Protestant part of the country; Twente in the Roman Catholic part. As a result of this, many inhabitants of Twente are Roman Catholic. However, in the 19th century religious diversity increased. Protestants started to live in Roman Catholic areas and vice versa. Furthermore, the Protestant church became very fragmented, which had its own demographic consequences. During the 19th century the fragmentation became more visible due to the foundation of new denominations (Hak, 1995). Religion is mainly an individual characteristic, but in the 19th century it was often clustered in regions (Beekink et al, 2003).

\section{DATA AND METHODS}

This study is based on data of the HSN, webrelease 2019_01. The HSN is a $0.75 \%$ sample taken from the birth registers from the Netherlands. The database for Overijssel covers people born between 1812 and $1912(\mathrm{~N}=4239)$. The birth certificates are combined with data from marriage and death certificates. The studied data does not include information on persons who migrated outside the province of Overijssel. In this study the choice has been made to use the data only for those who were born and died in Overijssel. We can be sure that such people lived a considerable period of time in the province, and that the specific environment had some influence on their life expectancy.

In addition to the HSN data, a number of other sources were used in this study. For example, our measure for the degree of industrialization in a particular place is based on a study by Janssens, Messling, and Need (2010). They distinguished four criteria to determine whether or not a place was industrialized or not. Using their criteria, Almelo, Enschede, Hengelo, and Oldenzaal can be characterized as industrial.

Religion is studied with the use of the Historische Databank Nederlandse Gemeenten (HDNG; Historical database of Dutch municipalities), in particular to derive a measure of the proportion of Catholic inhabitants. The proportion of Orthodox Protestants is calculated using the number of voters for the Staatskundige Gereformeerde Partij (SGP) at the municipality elections in 1933. Although the elections are not within the temporal boundaries of this study, the outcomes are considered to be representative for the period (Bras \& Schumacher, 2019).

In this article the influence of each of the factors on life expectancy will be analyzed using Cox regression analysis. The studied factors are: birth cohort, gender, social class, religion, religious climate of a place, inheritance law (partible or impartible inheritance), urbanization, and industrialization of communities. The multivariate Cox regression analysis shows the relative risks of dying in a certain period of time. Time is defined by the years lived from birth to death. The Cox regression shows ratios between groups and gives as an outcome how much larger the relative risk of dying is for each category of a variable compared to the reference category.

\section{RESULTS}

Table 1 presents both descriptive and multivariate results. The results show that birth cohort is an important factor in understanding life expectancy. The yearly likelihood of dying in cohort 1812-1831 is for example $11.6 \%$ higher than in the reference cohort 1891-1912. The last cohort shows the most progression; in contrast to the preceding cohort the risk of dying declined by $53 \%$. So, there is a strong positive relation in 
survival chances according to whether someone was born in a later cohort. This is not surprising. Most of the progression in Dutch life expectancy took place after 1880 (Beekink et al., 2011). In Overijssel, the effects seem not to be present in the cohort 1872-1891, but the results do show clear progression after 1891.

Table 1

Cox regression of life expectancy in Overijssel

\begin{tabular}{|c|c|c|c|c|}
\hline & $\mathrm{N}$ & Percentage & $\operatorname{EXP}(B)$ & $\mathrm{p}$-value \\
\hline \multicolumn{5}{|l|}{ Birth cohort } \\
\hline $1812-1831$ & 542 & $12.8 \%$ & 2.169 & $0.000 * * *$ \\
\hline $1832-1851$ & 746 & $17.6 \%$ & 1.904 & $0.000 * * *$ \\
\hline 1852-1871 & 1,028 & $24.3 \%$ & 1.772 & $0.000 * * *$ \\
\hline 1872-1891 & 863 & $20.4 \%$ & 1.531 & $0.000 * * *$ \\
\hline 1892-1912 & 1,060 & $25.0 \%$ & Ref. & Ref. \\
\hline \multicolumn{5}{|l|}{ Gender } \\
\hline Male & 2,173 & $51.3 \%$ & Ref. & Ref. \\
\hline Female & 2,066 & $48.7 \%$ & 0.815 & $0.000 * * *$ \\
\hline \multicolumn{5}{|l|}{ Social class } \\
\hline Elite & 100 & $2.4 \%$ & 0.926 & 0.463 \\
\hline Lower middle class & 552 & $13.4 \%$ & 0.928 & 0.151 \\
\hline Farmers & 1,081 & $26.2 \%$ & 1.002 & 0.969 \\
\hline Skilled Laborers & 1,202 & $29.1 \%$ & 0.921 & $0.044^{*}$ \\
\hline Unskilled Laborers & 1,196 & $29.0 \%$ & Ref. & Ref. \\
\hline \multicolumn{5}{|l|}{ Religion: percentage Roman Catholics } \\
\hline Municipality with $<10 \%$ Roman Catholics & 3,222 & $76.0 \%$ & 0.931 & 0.209 \\
\hline Municipality with $10 \%-60 \%$ Roman Catholics & 817 & $19.3 \%$ & 0.985 & 0.771 \\
\hline Municipality with $>60 \%$ Roman Catholics & 169 & $4.0 \%$ & Ref. & Ref. \\
\hline Unknown & 31 & $0.7 \%$ & - & - \\
\hline \multicolumn{5}{|l|}{ Religion: percentage of Orthodox Protestants } \\
\hline Municipality with $<1 \%$ Orthodox Protestants & 965 & $22.8 \%$ & 1.078 & 0.344 \\
\hline Municipality with $1 \%-10 \%$ Orthodox Protestants & 2,629 & $62.0 \%$ & 1.232 & $0.011^{*}$ \\
\hline Municipality with $>10 \%$ Orthodox Protestants & 635 & $15.0 \%$ & Ref. & Ref. \\
\hline Unknown & 10 & $0.2 \%$ & - & \\
\hline \multicolumn{5}{|l|}{ Inheritance law } \\
\hline Partible inheritance & 1,483 & $35.0 \%$ & Ref. & Ref. \\
\hline Impartible inheritance & 2,756 & $65.0 \%$ & 1.010 & 0.809 \\
\hline \multicolumn{5}{|l|}{ Urbanisation } \\
\hline Municipality with 10,000 to 100,000 inhabitants & 1,225 & $28.9 \%$ & 1.349 & $0.000 * * *$ \\
\hline Municipality with 5,000 to 10,000 inhabitants & 1,197 & $28.2 \%$ & 1.167 & $0.011^{*}$ \\
\hline Municipality with 2,000 to 5,000 inhabitants & 1,382 & $32.6 \%$ & 1.161 & $0.011^{*}$ \\
\hline Municipality with less than 2,000 inhabitants & 435 & $10.3 \%$ & Ref. & Ref. \\
\hline \multicolumn{5}{|l|}{ Industrialisation } \\
\hline Non-industrial municipality & 3,793 & $89.5 \%$ & Ref. & Ref. \\
\hline Industrial municipality & 446 & $10.5 \%$ & 1.031 & 0.582 \\
\hline
\end{tabular}

Note: Significance levels: ${ }^{* *}=p<0,001,{ }^{*}=p<0,01$ and ${ }^{*}=p<0.05$.

Source: Historical Sample of the Netherlands. HSN web release_2019_01. 
The likelihood of dying for women is $18.5 \%$ less than for men in the period under research. Skilled laborers had an $8 \%$ lower risk of dying than unskilled laborers. For the other social classes there are no significant differences. This confirms our expectations.

Inhabitants of municipalities with few Orthodox Protestants (1\%-10\% Orthodox Protestants) have a relatively higher risk of dying (23\%) than inhabitants living in municipalities with many Orthodox Protestants (> 60\%). This is contrary to the outcome we expected, namely that municipalities with many Orthodox Protestants had a higher risk of dying, perhaps because vaccination rates were lower. Similarly, although the literature predicts more child mortality in Catholic municipalities, the Cox regression does not show this outcome for life expectancy. Impartible inheritance also shows no significant relation with life expectancy in 19th-century Overijssel. Furthermore, the level of industrialization also fails to explain differences in life expectancy.

Urbanization did have a big impact on life expectancy. A yearly 34.9\% higher risk of dying in cities with more than 10,000 inhabitants, compared to the reference category comprising the smallest municipalities $(<2,000$ inhabitants). A possible explanation for this is that the quality of life in Overijssel cities improved quite late. It might be possible that a better environment in the city only became a fact since the 20th century. The expected reversal from an urban penalty to an urban premium had not yet taken place in late 19th-century Overijssel (Wolleswinkel-van den Bosch, van Poppel, Looman, \& Mackenbach, 2001).

\section{CONCLUSION}

The most important outcome of previous debates on life expectancy in the Netherlands was that regional differences were important (Beekink et al., 2011). A regional focus seemed better suited to determine which factors had the greatest impact on life expectancy. The province of Overijssel has barely been studied, even though it is an interesting province due to a variation in characteristics such as religion (Roman Catholic and Orthodox Protestant), industrialization, and inheritance laws.

This study examined seven different factors and their influence on life expectancy in 19th-century Overijssel. At the start of the 19th century life expectancy was, compared to other provinces, fairly good. But while in the rest of the Netherlands life expectancy increased rapidly in the following decades, life expectancy in Overijssel increased much more slowly. It was not until 1870 that people in Overijssel began to live longer, and the big leap forward only took place in the last studied cohort (1891-1912). Women had an 18.5\% longer life than men in the studied period. This is something which is quite well known and seen in most of the Dutch provinces.

Another factor of study consisted of the 'Catholic demographic patterns', which appeared to have barely any influence on life expectancy. Mixed religious municipalities turned out to be places with a lower life expectancy.

Chances of staying alive in Overijssel were better in municipalities with less than 2,000 inhabitants. In such small communities, with self-sufficient farmers, there was likely more mutual support (noaberschap). This outcome would be interesting to investigate in further research; do close neighborhood relations positively influence life expectancy and where are they most present?

A factor which has not been studied to any great extent is the Anerbenrecht, the impartible inheritance custom which was common in the agrarian part of East Overijssel. This could have impacted family relations and the amount of care for family members. But the Cox regression hardly showed any differences between municipalities with Anerbenrecht and those without. A possible explanation for this is a problem in the sources. This study used the municipality as the criterion, but this is not the best option. If it had been possible to study Anerbenrecht and life expectancy on a household scale the outcomes might have been different.

In conclusion, life expectancy in Overijssel developed steadily for the better between 1812 and 1912 . The most important factors associated with the increasing life expectancy were, besides the most important factor of birth cohort, differences in the level of urbanization and the share of Catholics and Protestants in a municipality. Besides these outcomes, the method used in this study had never previously been applied to Overijssel. The use of the HSN and additional data gave a thorough insight into life expectancy in Overijssel. Due to data constraints this study is not comprehensive; a bigger dataset and more personal information 
could have given better insights. Migration is a factor which can influence life expectancy as well, and is not taken into account in this study. So, as this study is one of the first specific studies regarding life expectancy in Overijssel between 1812 and 1912, a lot of work remains to be done.

\section{REFERENCES}

Beekink, E., Boonstra, O., Engelen, T., \& Knippenberg, H. (Eds.). (2003). Nederland in verandering. Maatschappelijke ontwikkelingen in kaart gebracht 1800-2000. Amsterdam: Aksant.

Bras, H., \& Schumacher, R. (2019). Changing gender relations, declining fertility? An analysis of childbearing trajectories in 19th-century Netherlands. Demographic Research, 41(30), 873-912. doi: 10.4054/DemRes.2019.41.30

Bras, H., \& van Tilburg, T. (2007). Kinship and social networks: A regional analysis of sibling relations in twentieth-century Netherlands. Journal of Family History, 32(3), 296-322. doi: $10.1177 \% 2 F 0363199007300244$

Engelen, T. (2009). Van 2 naar 16 miljoen mensen. Demografie van Nederland, 1800-nu. Amsterdam: Boom.

Hak, D. (1995). Over secularisering, ontkerkelijking en individualisering. Enige uitkomsten van recent godsdienstsociologisch onderzoek in Nederland. Sociologische Gids, 42(2), 124-139. Retrieved from https://ugp.rug.nl/sogi/article/view/19719

Historical Sample of the Netherlands. (n.d.). HSN web release 2019_01. Retrieved from http://www. iisg.nl/hsn/data/downloadservice.php

Janssens, A., Messelink, M., \& Need, A. (2010). Faulty genes or faulty parents? Gender, family and survival in early and late childhood in the Netherlands, 1860-1900. The History of the Family, 15(1), 91-108. doi: 10.1016/j.hisfam.2010.01.005

van Zanden, J. L. (1994). Industrialisatie en inkomensverdeling in Overijssel, 1750-1875. BMGN Low Countries Historical Review, 109(3), 434-449. doi: 10.18352/bmgn-Ichr.3870

van Zanden, J. L., \& van Riel, A. (2004). The strictures of inheritance: The Dutch economy in the nineteenth century. Princeton: Princeton Universitary Press.

Wolleswinkel-van den Bosch, J., van Poppel, F. W. A., Looman, C. W. N., \& Mackenbach, J. P. (2001). The role of cultural and economic determinants in mortality decline in the Netherlands, 1875/1879-1920/1924: A regional analysis. Social Science \& Medicine, 53(11), 1439-1453. doi: 10.1016/S0277-9536(00)00417-2 